\title{
Attitudes of Teachers from Mainstream Schools to Education Including Children with Disabilities
}

\begin{abstract}
The article presents a study whose aim was to learn the attitudes of teachers of upper elementary grades from mainstream schools to education including students with disabilities. It was also an attempt to learn their opinions on the chances and limitations of implementing inclusive assumptions in educational practice as well as their needs and expected support in the performance of professional tasks related to teaching students with disabilities. The study involved 145 teachers of grades 4-8 of elementary schools. The following research tools were used: The Scale of Teachers' Attitudes to Inclusive Education, developed on the basis of the Survey of Attitudes Toward the Inclusion of Students with Special Needs by M.A. Winzer (Polish adaptation by W. Pilecka \& J. Kossewska), and a survey questionnaire for teachers. The obtained results show that many teachers approach skeptically the new solutions in education for students with disabilities. Their ambiguous or negative attitude to inclusive education corresponds to the sense of lack of proper preparation to teaching students with disabilities and a critical assessment of the state of readiness of mainstream schools (both in formal and social/mental terms) to the implementation of educational inclusion assumptions.
\end{abstract}

\section{Keywords:}

inclusive education, attitude, teachers, students with disabilities

Faculty of Education, University of Białystok, Poland.

E-MAIL: agnieszka.sakowicz@uwb.edu.pl ORCID: 0000-0001-5595-8249 


\section{INTRODUCTION}

The evolution of the paradigmatic cognitive perspective concerning people with special educational needs, especially the departure from the adaptation model in favor of the emancipatory and normalization paradigms as the foundation of social inclusion, sets new standards, not only as regards theory and education, but first of all, application, improving the quality of life and the well-being of people who are marginalized in educational, cultural and social terms. These changes in the educational sphere result in the transformation of the form of educational policy towards inclusive education.

It is commonly agreed that inclusive education is the main, if not the only, way to provide education respecting the basic rights of an individual, specified in documents such as the Universal Declaration of Human Rights, the international Convention on the Rights of the Child, or more recent ones, e.g., the Convention on the Rights of Persons with Disabilities (Jachimczak, 2018, p. 34).

The idea of inclusive education involves the effort to develop a common starting plane for all students, respecting their right to be together despite differences, and respecting the subjectivity of each student. It is the departure from categorizing children in terms of their developmental and medical needs or cultural identity in favor of building an educational community in which students' diversity is perceived as something normal, as an added value, and as a learning potential.

Inclusive education is based on respect for the following general principles:

1. children are not equal but have an equal right to develop;

2. each child had the right to attend a mainstream school, because each human has an equal right to participate in the social life;

3. the teacher/educator must have a flexible attitude, so he or she needs to have a flexible, open mind;

4. children are not taught. Children learn;

5. it is not the curriculum that matters; it is the child that matters. The concept of a curriculum should be replaced with the concept of a child development plan. High flexibility is needed to effectively combine the two elements of the process: the child and the plan of their development;

6. a child does not have deficits but abilities;

7. the role of the school is to integrate, not to divide;

8. diversity is a gift allowing the child to better understand the world, which is diverse. Thus, the multiplicity of characters, cultures, abilities, etc., in the 
classroom is not a danger but an opportunity for better development (Lebeer et al., 2013, p. 11).

New educational challenges, based on the values of equality and fairness, impose a great obligation and responsibility on mainstream schools. They implicate the need to revise the school's previous conditions and organizational culture, the applied methods, forms of didactic and educational work, to adjust the physical environment and the technological base to the students' varied developmental and educational needs and psychophysical capabilities. They also result in new requirements of educational and axiological competences of the teacher as the main performer of the inclusive assumptions of the school. The European Agency for Development in Special Needs Education (2012) lists the following values and areas of competence of teachers working in mainstream schools in the document "Profile of Inclusive Teachers" (2012, pp. 13-19):

1. valuing learner diversity - learner difference is considered as a resource and an asset to education. The areas of competence within this core value relate to: a) conceptions of inclusive education; b) the teacher's view of learner difference,

2. supporting all learners - teachers have high expectations for all learners' achievements. The areas of competence within this core value relate to: a) promoting the academic, practical, social and emotional learning of all learners; b) effective teaching approaches in heterogeneous classes,

3. working with others - collaboration and teamwork are essential approaches for all teachers. The areas of competence within this core value relate to: a) working with parents and families; b) working with a range of other educational professionals,

4. personal professional development - teaching is a learning activity and teachers take responsibility for their lifelong learning. The areas of competence within this core value relate to: a) teachers as reflective practitioners; b) initial teacher education as a foundation for ongoing professional learning and development (2012, pp. 13-19).

The new perspective of education requires teachers to be reflective, creative, open to educational innovations and collaboration with others, willing to expand their knowledge and skills necessary to create an inclusive educational environment. The results of studies on teachers' competence for working with a heterogeneous group carried out in recent years are not optimistic (i.a., Al-Khamisy, 2013; Buchnat, 2014; Chrzanowska, 2010, Gajdzica, 2011; Uberman \& Mach, 2016). 
Although teachers tend to have a positive attitude to inclusive education and more and more teachers are making an effort to improve their competence in that regard (through participation in various workshops, courses and post-graduate programs), their level of preparation to teaching students with special educational needs is still insufficient (also in the opinion of those teachers). They have fears and anxieties related to the introduced educational changes, often resulting from insufficient knowledge of the basic assumptions of inclusive education, understanding its essence or the lack of experience in working with students with disabilities.

This situation is important because - as pointed out by the authors of the report of the European Agency for Special Needs and Inclusive Education, ${ }^{2}$ the process of inclusion largely depends on teachers' attitudes to students with special educational needs, their views on differences in the classroom, and their readiness to deal effectively with those differences. Generally, teachers' attitude was considered to be the decisive factor in schools becoming more inclusive.

It must be noted that so far, in empirical works on education the researchers most often focused on the knowledge and competence of early education teachers (grades 1-3) of mainstream elementary schools and their attitude to educational changes in teaching students with special educational needs (i.a., Al-Khamisy, 2013; Skibska, 2016; Szumski, 2010; Uberman \& Mach, 2016; Zamkowska, 2009). The area concerning the attitudes, competence and knowledge of teachers of upper elementary grades and middle schools still needs in-depth analyses. This problem seems important if we assume that "inclusive education should concentrate on adjusting the requirements, conditions and organization of learning to the student's needs from the perspective of their lifelong education, including vocational training and entering and participation in the labor market. Teachers at this level participate in the longest stage of the students' educational process (jointly lasting 8-10 years) and should be perfectly well prepared to carrying out their responsibilities" (Jachimczak, 2019, p. 145).

\section{MATERIAL AND METHODS}

The aim of the research was to learn the attitudes of teachers of grades 4-8 of mainstream elementary schools to education including students with disabilities.

2 Report Inclusive Education and Educational Practice developed by the European Agency for Special Needs and Inclusive Education (2003); cited in: European Agency for Special Needs and Inclusive Education (2014). Five Key Messages for Inclusive Education. Putting Theory into Practice. Odense, Denmark: European Agency for Special Needs and Inclusive Education, p. 19. 
It was also an attempt to learn their opinions on the chances and limitations of implementing inclusive assumptions in educational practice as well as their needs and expected support in the performance of professional tasks related to teaching students with disabilities.

The following research questions were asked:

- What attitude towards inclusive education are declared by teachers working in grades $4-8$ of elementary schools?

- What is the teachers' opinion on the chances of success of inclusive education in relation to students with and without disabilities?

- What is the teachers' opinion on the state of readiness of their schools to implement the assumptions of educational inclusion?

- How do teachers assess their preparation for work with students with disabilities?

- What support do teachers expect in the implementation of the inclusive education process?

The research was conducted with the use of diagnostic poll. The teachers' attitudes were studied with the use of the Scale of Teachers' Attitudes to Inclusive Education modeled on the Survey of Attitudes Toward the Inclusion of Students with Special Needs by Margaret A. Winzer adapted by Władysława Pilecka and Joanna Kossewska (Kossewska, 2000, pp. 285-286). The scale is made up of 20 items, including 12 that reflect a positive attitude to the idea of inclusion and 8 that reflect a negative attitude to it. Each statement is assessed in the 1 to 5 scale, where: 1 - 'completely disagree', 2 - 'somewhat disagree', 3 - 'hard to say', 4 - 'somewhat agree', 5 - 'completely agree'. The questionnaire was used to characterize the studied group of teachers (age, work experience as teachers, experience in teaching persons with disabilities, professional preparation) and to learn their opinions on the chances of success and limitations of implementing the inclusive assumptions in the educational practice.

The study involved 145 teachers of grades $4-8$ of mainstream elementary schools. The largest group (55.9\%) was persons with over 11 years of experience as teachers. Nearly $20 \%$ were people working as teachers for $6-10$ years, and 1/4 had up to 5 years of experience. The vast majority of the teachers (87.6\%) had some experience in teaching students with disabilities; $42.8 \%$ of them declared a lot of experience, and $44.8 \%$, little. $12.4 \%$ of the respondents reported they had no experience in it. 


\section{RESEARCH RESULTS}

The analysis of the data showed that slightly more than a half of the studied teachers (54.5\%) declared a positive attitude to inclusive education. Nearly $1 / 3$ of the teachers displayed an ambiguous attitude, and $14.5 \%$ had a negative attitude to this form of education.

Teachers' views concerning the chances of success of inclusive education differed depending on the group of reference. In the case of students without disabilities, most respondents (72.4\%) regarded inclusion as a good educational solution. It was argued that by learning together, they would learn tolerance, acceptance and empathy. Mutual help, support and the development of sensitivity and understanding of other people's differences are also an added value.

The teachers were much more skeptical regarding the chances of success of education including students with disabilities. Only 1/10 respondents thought all children, regardless of the kind and degree of dysfunction, should learn together with their peers in general education classes. Those teachers argued that "students with disabilities should not be deprived of the opportunity to meet healthy children". It was stressed that in the case of students with disabilities, the greatest benefit from learning together with non-disabled peers was the sense of belonging to a group. The importance of inclusive education in building and enhancing selfesteem of a child with a disability was also stressed.

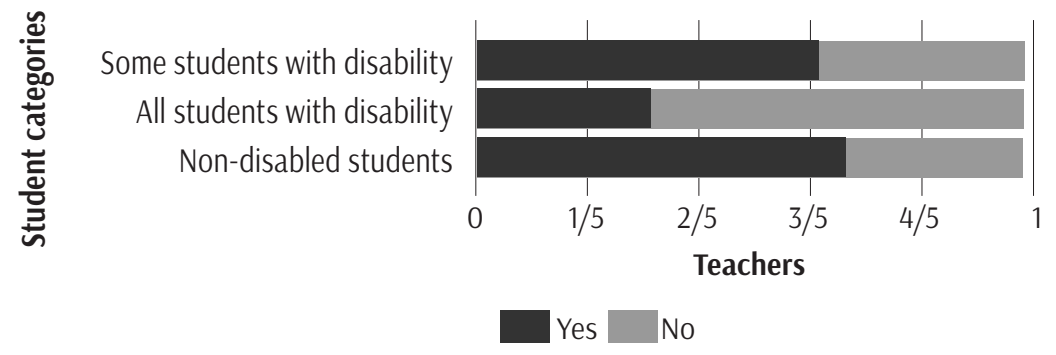

Figure 1. Teachers' Opinions on the Chances of Success of Education Including Students with and without Disabilities

Source: author's own study.

Another view was represented by 2/3 of the teachers, who regarded the kind and degree of disability as factors significantly decisive for including the students into a general education class. For them, students with mild disability stand much higher chances of success in inclusive education than do students with moderate or 
severe disability. They argued that "students with severe disability need a different level of teaching and different conditions", and that "mainstream schools do not have sufficient equipment and the classes are too big". The distribution of mean results (Fig. 2) shows that they evaluated the most positively (as high) the chances of educational success of students with mild intellectual disability $(M=4.10$; $\mathrm{SD}=1.40)$ and students with hearing impairments $(\mathrm{M}=3.83$; $\mathrm{SD}=0.73)$. Slightly lower scores (but above the average) were achieved for students with motor dysfunction ( $\mathrm{M}=3.51 ; \mathrm{SD}=1.06)$, vision impairment $(\mathrm{M}=3.51 ; \mathrm{SD}=1.02)$, and autism $(\mathrm{M}=3.39$; $\mathrm{SD}=1.69)$. The educational chances of students with chronic diseases $(M=3.19 ; S D=0.50)$ and with Asperger syndrome $(M=3.09 ; S D=1.04)$ were evaluated as average. According to the teachers, students with speech (communication) impairment $(\mathrm{M}=2.80 ; \mathrm{SD}=0.98)$, moderate or severe intellectual disability $(M=2.78$; $S D=1.03)$, as well as deaf $(M=2.61 ; S D=1.09)$, blind $(M=2.56$; $\mathrm{SD}=1.99)$ and those with multiple disabilities $(\mathrm{M}=2.61$; $\mathrm{SD}=0.89)$ have the lowest chances of success (mean values below the average).

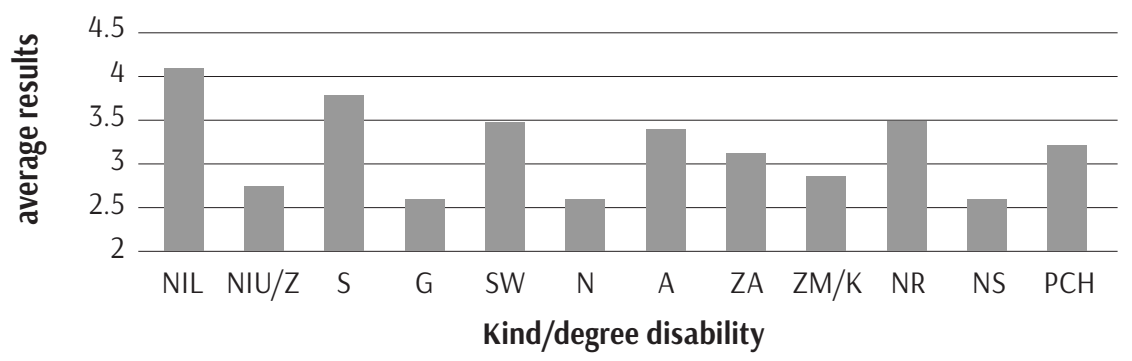

Figure 2. Teachers' Opinions on the Chances of Success of Education Including Particular Groups of Students with Disabilities

MID - persons with mild intellectual disability, MSID - with moderate/severe intellectual disability, $\mathrm{HI}$ - with hearing impairment, D - deaf, VI - with vision impairment, B - blind, A - autistic, AS - with Asperger syndrome, $\mathrm{SCl}$ - with speech/communication impairment, MD - with motor dysfunction, MDS - with multiple disabilities, and CD - with a chronic disease.

Source: author's own study.

The next step of research was an attempt to find out how teachers assess the state of readiness of their mainstream schools to carry out the assumptions of educational inclusion. The following aspects were analyzed: 1) architectural and technological preparation of the school, 2) organization of psychological and pedagogical assistance, 3) collaboration with the students' family environment, 4) teachers’ preparation to teaching students with disabilities. 
The distribution of the mean scores of the variables (Figure 3) shows that the teachers assessed the lowest $(\mathrm{M}=3.02 ; \mathrm{SD}=1.18)$ the state of preparation of their schools in terms of architecture and the technological-didactic base. Only $1 / 3$ of the respondents believed their schools were well prepared to carrying out the assumptions of inclusive education in this regard. The explanation usually referred to the liquidation of architectural barriers with respect to the needs and developmental capabilities of students with motor disability (lifts, ramps, toilet adjustment). Appropriate technological and didactic equipment was much less often mentioned. The remaining teachers either assessed negatively the architectural and technological adjustment of their schools to the needs of students with disabilities or did not know how to answer (33.3\% in each group).

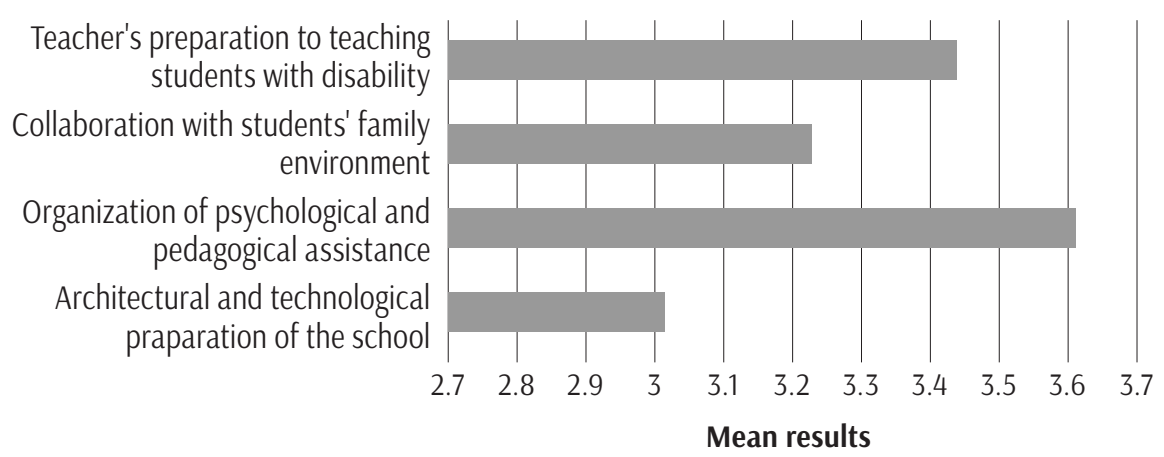

Figure 3. Mean Values of Teachers' Assessment of the State of Readiness of Their Mainstream Schools to Carrying Out the Assumptions of Inclusive Education

Source: author's own study.

Collaboration between the school and the students' family environment was evaluated slightly higher, as average $(\mathrm{M}=3.23$; $\mathrm{SD}=0.94)$. Most teachers (85.5\%) expressed moderate satisfaction with collaboration with parents, assessing it as average or good. $14.5 \%$ respondents had an opposite view. Regarding the question: "Is inclusive education approved by the parents of children with and without disabilities?”, they more often gave a positive response considering the guardians of students with disabilities $(\mathrm{M}=3.66$; $\mathrm{SD}=0.96)$ than the guardians of non-disabled children ( $M=3.06$; $S D=0.92)$. Nearly half the teachers (46.9\%) believed this form of education was approved by the parents of children with disabilities. A similar number (44.8\%) did not know, and 8.3\% answered negatively. On the basis of their own experience in contacts with parents and conversations with other teachers, the respondents supported their positive stance with the fact that this situation is 
beneficial both for students with disabilities and for their parents: "the school is close to their home, they don't need to drive the child to school; parents have a direct influence on what happens in the class and school of their disabled child; they want their children to imitate non-disabled children; parents can observe progress in their child's development and see a greater chance for that development". The teachers were much more skeptical in formulating their opinion on the attitude of parents of non-disabled children to inclusive education. 37.2\% of them mentioned those parents' approval, arguing that "parents understand the situation of children with disabilities and their parents", "they sympathize with the parents of children with disabilities", "they are aware that their children learn tolerance, acceptance, understanding of diseases, sensitivity and ability of cooperation". 62.8\% teachers had the opposite view. According to them, the parents of non-disabled children do not approve of this form of education because they "fear the ill children", "fear the threat", or "think that students with disabilities absorb more of the teacher's time" and "the quality of teaching is lower".

The analysis of research results showed that the teachers assessed the highest (as good) the preparation of schools in terms of the organization of psychological and pedagogical assistance $(\mathrm{M}=3.62 ; \mathrm{SD}=0.70)$. Almost $2 / 3$ of the respondents shared this opinion. 1/4 assessed the organization of psychological and pedagogical assistance in their schools as medium, and 1/5, as low. In response to the question: "How is your school prepared to carrying out the assumptions of inclusive education in terms of pedagogical and pedagogical assistance?", the respondents most often mentioned such forms of support as the assistance of a speech therapist, an educational counselor, a psychologist, participation in didactic and compensatory classes, corrective and compensatory classes, revalidation classes and ability development classes.

One of the basic conditions of effectiveness of inclusive education is the proper preparation of teachers to teaching students with disabilities. Calculations show that in the studied group of teachers, it was assessed as medium $(M=3.46$; $\mathrm{SD}=0.68$ ). The distribution of percentage data shows that almost $1 / 3$ of the teachers considered their preparation to be good, and more than half (53.8\%) assessed it as medium. The remaining $15.2 \%$ declared having no or little preparation to teaching children with disabilities.

The teachers' responses show that they mainly acquire knowledge on how to work with children with disabilities from the Internet and source literature: 1/5 of the respondents declared using those sources. Slightly fewer respondents receive the information they need from other teachers, the educational counselor, the school psychologist and the children's parents. The least often mentioned source 
of knowledge was participation in organized forms of training in special needs education (training sessions, specialist courses, workshops, postgraduate courses), only declared by fewer than $10 \%$ of the respondents.

As many as $2 / 3$ of the respondents agreed that they need extra support in carrying out their professional tasks. Most of them declared the need to increase the level of knowledge and competence to work with students with disabilities through participation in workshops and courses. They mostly expected assistance in this regard from the school principals and from specialists from the psychological and pedagogical counseling center. They also pointed to the need for regular collaboration with the psychological and pedagogical counseling center and for greater engagement of parents in their children's education. Attention was also given to organizational issues, such as the liquidation of architectural barriers with respect to the needs and developmental capabilities of students with motor disability, equipping classrooms with relevant teaching aids, smaller classes, and employing a supporting teacher. Very few responses referred to the need for support from the educational counselor or school psychologist, which may mean that the respondents consider the received assistance as satisfactory.

\section{DISCUSSION}

The obtained research material proves that teachers from mainstream schools treat skeptically the new solutions in educating students with disabilities. Half of the participating teachers declare a positive attitude to inclusive education, and the others display an ambiguous or negative attitude. Although they can see the benefits of learning together for both groups of students, they much more often associate the benefits with non-disabled than disabled students. In their opinion, students with mild disability have the greatest chance of success in inclusive education. The chances of school success of students who are blind, deaf, have more severe intellectual disability or multiple disabilities are usually assessed as little. This situation is confirmed by a study carried out by Marta Uberman and Aleksandra Mach (2016). In that study, 72\% of the participating teachers considered the kind and degree of disability as factors decisive for the successful inclusion of students with disabilities in mainstream schools. The greatest challenge for the respondents is blind (73\%) and deaf (62\%) students, as well as those with moderate and severe intellectual disability (50\%) (Uberman \& Mach, 2016, p. 177). On the basis of their research, Zenon Gajdzica (2011) and Marzena Buchnat (2014) 
conclude that the vast majority of teachers do not support education for children with mild intellectual disability in mainstream schools.

It is noteworthy that this stereotypical view, based on the medical model of disability, is displayed by the vast majority of the studied teachers, including more than half of those who declared a positive attitude to inclusive education. The revealed discrepancies in the teachers' responses lead to a reflection on to what extent the declared approval of the introduced educational changes (expressed by at least some of them) result from their internal beliefs, and to what extent they are the result of "political correctness". It may be supposed that for some of the studied teachers, they are a kind of "protection argument" used to avoid the accusation of, e.g., the discrimination of persons with disabilities or the lack of openness to new professional challenges. According to Sławomira Sadowska (2016, p. 128), "approaching new solutions skeptically may be connected with the fact that teachers of mainstream schools try to avoid guilt and humiliation related to the failure to meet the requirements of competition and effectiveness in performing a new educational task". Moreover, the pressure from the so-called 'staff room mentality' makes those who are open to inclusion succumb to the voices that they should quickly forget about such 'smart ideas'. Such an attitude does not promote the implementation of the assumptions of inclusion in educational practices. To the contrary, "displaying resistance [which is often masked - author's note] makes effective implementation of reforms considerably more difficult, and sometimes even impossible” (Gajdzica, 2011, p. 60).

The analysis of research results leads to the conclusion that teachers' negative or ambiguous attitude to inclusive education corresponds to their lack of proper preparation to teaching students with disabilities and a critical assessment of the state of readiness of mainstream schools to carrying out the assumptions of educational inclusion. They can see many irregularities and superficial actions regarding the organization of inclusive educational environment, which they find to be unprepared to meeting new educational challenges in many aspects. Only few teachers declared their schools were prepared architecturally to the needs and developmental capabilities of students, and only in the case of motor dysfunction. The fact of the lack of meeting the needs of students with other kinds of disability, e.g., vision or hearing impairments, does not only show that the teachers assess critically the architectural and technological preparation of schools to accepting that group of students. More importantly, it also shows that they personally do not see this need. Without sufficient knowledge on the mental functioning of persons with different kinds of disability, they do not realize the existence of the need to provide physical and technological conditions of the educational space (following 
the principles of universal design) available for all students with varied capabilities, skills and levels of ability. It may also be presumed that the lack of reaction on the part of some teachers is a conscious decision, resulting from their belief that a special school is the form of education that best meets the developmental and educational needs of that group of students. "Insufficient knowledge and experience in teaching persons with disabilities causes fears of contact with that group of students, and in extreme cases it even leads to the refusal to teach them" (Sochańska-Kawiecka et al., 2015, p. 32).

Actually, this is not the only case in which teachers' attitudes were not consistent. Many teachers were also unable to provide a clear view concerning a number of other issues of key importance for inclusive education, e.g., collaboration with parents, specialists, or their own needs and expected support in the performance of the new professional challenges. All this clearly shows the real situation. Hence, the declared teachers' preparation to teaching students with disabilities (especially at the 'good' level) should be regarded as very much exaggerated in comparison to the real situation, and in the face of new educational challenges, as definitely insufficient. The implied conclusion of the low level of preparation of teachers from mainstream schools to teaching students with special educational needs is confirmed in studies by other authors (Al-Khamisy, 2013; Gajdzica, 2011; Barłóg, 2008; Jachimczak, 2018; Zamkowska, 2009, 2011).

"New challenges require teachers to revise the forms, methods and means of educational work they have used so far. They impose the necessity to improve teachers' competence, to manage the didactic and educational process and to solve problems in ways other than before" (Jurewicz, 2013, p. 118). So as to be able to effectively cope with problems, teachers have to use various areas of knowledge and skills, take the initiative, ask for help and actively seek it (Leśniewska \& Puchała, 2011). The obtained results indicate that teachers are aware of the need to improve their own professional competence and point out they need support in this area, but they do not do much to change this situation. Fewer than $10 \%$ of the teachers have made an extra effort to improve their competence by means of postgraduate courses in special needs pedagogy. The majority of the respondents limit their activities to looking for information on the Internet and in specialist literature.

Better preparation may be the result of not only teachers' personal professional development, but also a shared vision of the school implemented by all who work there: the whole pedagogical staff, teachers and specialists employed at the school together with the principals, students' parents and the local community (Skotnicka, 2017, pp. 75, 81). Discussing problems together, exchanging experi- 
ences and sharing advice and observations from the daily professional practice are invaluable in building an inclusive community. Research results suggest that teachers can see this fact and attach more and more importance to collaboration with specialists from the psychological and pedagogical counseling center, school educational counselor, school psychologist and other teachers. Some insufficiency is visible with regard to the support received from the school principals. Therefore, there is a need for them to engage more in creating conditions promoting the inclusion process, e.g., through organizing workshops for teachers, establishing cooperation with special schools, adjusting the physical environment to the developmental and educational needs of students with various disabilities, etc.

An important element whose potential is not properly used in building the inclusive educational environment, is the students' parents. The teachers' view concerning the parents' attitude to inclusive education seems to be revealing a lot. Whereas the teachers' poor knowledge on the attitude of parents of children with disabilities to inclusive education diagnosed in the study may be the result of their lack of or little professional experience (contacts) with that group of people, the negative evaluation concerning the parents of non-disabled children provokes to deeper reflection on the quality of collaboration between schools and parents. Of key importance is the attitude of teachers as those who serve as opinion-makers, the organizers of school work, and behavior models for children and parents. It may be presumed that the numerous fears and anxiety visible in many teachers, and even the lack of conviction that including students with disabilities in general, mainstream education is right, do not help parents (especially the parents of healthy children) develop a positive attitude to the implemented educational changes.

Inclusive education is a complex process, "so innovative in relation to the present educational practice that in order to implement it, the 'school spirit' and the mentality of people working there and using its services need to be changed" (Szumski, 2013, p. 35). Cooperation between different school subjects - students, teachers, parents and revalidation specialists - is one of the main areas that definitely need to be improved. The thing is the awareness of the community of goal and responsible participation of those persons in building an educational space open to the diversity of the children who study there. The most important entity determining the effectiveness of the introduced educational changes is teachers (Chrzanowska, 2018; Hughes, 2006; Janiszewska-Nieścioruk \& Zaorska, 2014; Marin, 2014; Ross-Hill, 2009). It is their engagement and belief in the value of the process of including students with disabilities into mainstream education that is largely decisive for the success of the process. "Teachers also need to see them- 
selves as lifelong learners. They need to develop skills in research and use of research findings. Interpersonal skills and an understanding of the nature of collaboration are essential to work with others, including professionals and parents who contribute to a full understanding of learners' needs" (European Agency for Development..., 2011). For them to meet this challenge, it is necessary to work out the proper model of teacher support based on thorough exploration of their educational resources, needs, and expectations. The model of "support which means that they will not be alone in the face of potential problems or doubts but they will be sure that they make the right decisions and find the answers to their questions: the support that will help provide for the needs of all students in the best way possible" (Skotnicka, 2016, p. 176).

\section{References}

Al-Khamisy, D. (2013). Edukacja włq̨czajq̨ca edukacjq dialogu. W poszukiwaniu modelu edukacji dla ucznia ze specjalnymi potrzebami edukacyjnymi. Warszawa: Wydawnictwo Akademii Pedagogiki Specjalnej.

Barłóg, K. (2008). Wspomaganie rozwoju dzieci z niepełnosprawnościq intelektualnq w stopniu lekkim w rożnych formach edukacji wczesnoszkolnej. Rzeszów: Wydawnictwo Uniwersytetu Rzeszowskiego.

Buchnat, M. (2014). Kompetencje i oczekiwania nauczyciela do pracy z dzieckiem ze specjalnymi potrzebami edukacyjnymi. Komunikat z badań. Studia Edukacyjne, 31, pp. 177-193.

Chrzanowska, I. (2010). Problemy edukacji dzieci i młodzieży z niepełnosprawnościq. Regionalna specyfika czy ogólnopolska tendencja. Kraków: Oficyna Wydawnicza „Impuls”.

Chrzanowska, I. (2018). Edukacja włączająca - wyzwanie dla kompetencji pedagogów specjalnych. Studia Edukacyjne, 48, pp. 23-32.

Dycht, M. (2017). Edukacja włączająca uczniów ze specjalnymi potrzebami edukacyjnymi w Polsce. In: M. Dycht (Ed.), Podnoszenie kompetencji nauczycielskich w pracy z uczniem o specjalnych potrzebach edukacyjnych w szkole ogólnodostępnej. Materiały dydaktyczne (pp. 9-14). Warszawa: Wydawnictwo Naukowe Uniwersytetu Kardynała Stefana Wyszyńskiego.

European Agency for Development in Special Needs Education (2011). Teacher Education for Inclusion Across Europe - Challenges and Opportunities. Retrieved from: https:// www.european-agency.org/resources/publications/teacher-education-inclusion-acrosseurope-challenges-and-opportunities [access date: 10.09.2019].

European Agency for Development in Special Needs Education (2012). Teacher Education for Inclusion. Profile of Inclusive Teachers. Retrieved from: https://www.european-agency. org/sites/default/files/Profile-of-Inclusive-Teachers.pdf [access date: 29.05.2019].

European Agency for Special Needs and Inclusive Education (2014). Five Key Messages for Inclusive Education. Putting Theory into Practice. Odense, Denmark: European Agency for Special Needs and Inclusive Education. Retrieved from: https://www.europeanagency.org/sites/default/files/Five\%20Key\%20Messages\%20for\%20Inclusive\%20Education.pdf [access date: 29.05.2019]. 
Gajdzica, Z. (2011). Opinie nauczycieli szkół ogólnodostępnych na temat edukacji włączającej uczniów z lekkim upośledzeniem umysłowym w kontekście toczącej się reformy kształcenia specjalnego. In: Z. Gajdzica (Ed.), Uczeń z niepełnosprawnościq w szkole ogólnodostępnej (pp. 56-82). Sosnowiec: Oficyna Wydawnicza „Humanitas” WSH.

Głodkowska, J. (2008). Różnice nie muszq dzielić - uczeń z niepełnosprawnościq w szkole ogólnodostępnej. Rozważania teoretyczne. Program w ramach inicjatywy Wspólnotowej dla Polski EQUAL: PRR - „Niepełnosprawni - samodzielność, rodzina, rehabilitacja, edukacja, praca - system zintegrowany” w Działaniu 2 oraz PRR - PEKiN w Działaniu 3. Warszawa: Fundacja Pomocy Ludziom Niepełnosprawnym.

Hughes, J. (2006). Inclusive Education for Individuals with Down Syndrome. Down Syndrome News and Update, 6(1), pp. 1-3. DOI: 10.3104/practice.370.

Jachimczak, B. (2018). Kształcenie nauczycieli dla edukacji włączającej. Studia Edukacyjne, 48, pp. 33-43.

Jachimczak, B. (2019). Nauczyciel w edukacji włączającej. In: I. Chrzanowska, \& G. Szumski (Eds.), Edukacja włączajq̨ca w przedszkolu i szkole (pp. 138-159). Warszawa: Fundacja Rozwoju Systemu Edukacji.

Janiszewska-Nieścioruk, Z., \& Zaorska, M. (2014). Prowłączające zmiany w systemie polskiej edukacji - nowe możliwości, ograniczenia i wyzwania. Interdyscyplinarne Konteksty Pedagogiki Specjalnej, 4, pp. 9-28. DOI: 10.14746/ikps.2014.4.01.

Jurewicz, M. (2013). Diagnozowanie możliwości i potrzeb rozwojowych dzieci - nowe perspektywy i ponadczasowe dylematy. Roczniki Pedagogiczne, 5(2), pp. 117-132.

Kossewska, J. (2000). Uwarunkowania postaw. Nauczyciele i inne grupy zawodowe wobec integracji szkolnej dzieci niepełnosprawnych. Kraków: Wydawnictwo Naukowe Akademii Pedagogicznej.

Lebeer, J., Gracio, L., Sart, Z.H., Schraepen, B., Babur, N., Van den Eynde, R., Stoffels, L., \& Gogacz, A. (Eds.) (2013). Profilaktyczne podejście w edukacji włączajq̨cej. Działania nauczycieli szkół podstawowych różnicujq̨ce pracę w klasie. Przewodnik zawodowy. Wersja polska. Beşiktaş/Istambuł: Wydawnictwo Boğaziçi University.

Leśniewska, K., \& Puchała, E. (2011). Organizacja procesu wspierania uczniów ze specjalnymi potrzebami edukacyjnymi. Retrieved from: https:/www.pppwalcz.com/pliki/pdf_02.pdf [access date: 28.01.2019].

Leśniewska, K., Puchała, E., \& Zaremba, L. (2011). Specjalne potrzeby edukacyjne dzieci i młodzieży: praca zespołu nauczycieli, wychowawców grup wychowawczych i specjalistów prowadzq̨cych zajęcia z uczniem w przedszkolach, szkołach i placówkach. Warszawa: Ministerstwo Edukacji Narodowej.

Marin, E. (2014). Are Today’s General Education Teachers Prepared to Face Inclusion in the Classroom? Procedia - Social and Behavioral Sciences, 142, pp. 702-707. DOI: 10.1016/ j.sbspro.2014.07.601.

Ross-Hill, R. (2009). Teacher Attitude Towards Inclusion Practices and Special Needs Students. Journal of Research in Special Educational Needs, 9(3), pp. 188-198. DOI: 10.1111/ j.1471-3802.2009.01135.x.

Sadowska, S. (2016). Kształcenie integracyjne dzieci z niepełnosprawnością intelektualną - krytyczny bilans pierwszych strukturalnych zmian w systemie edukacji. Przeglqqd Badań Edukacyjnych, 2(23), pp. 125-144. DOI: 10.12775/PBE.2016.076.

Skibska, J. (2016). Edukacja włączająca w opinii nauczycieli edukacji wczesnoszkolnej: analiza segmentacyjna. Doniesienia z badań. In: M. Bełza-Gajdzica, \& Z. Gajdzica (Eds.), Ink- 
luzja edukacyjna: idee, teorie, koncepcje, modele edukacji włączajq̨cej a wybrane aspekty praktyki edukacyjnej (pp. 161-174). Katowice: Wydawnictwo Uniwersytetu Śląskiego.

Skotnicka, B. (2016). Wsparcie społeczne nauczycieli edukacji inkluzyjnej. In: M. Bełza-

Gajdzica, \& Z. Gajdzica (Eds.), Inkluzja edukacyjna: idee, teorie, koncepcje, modele edukacji włq̨czającej a wybrane aspekty praktyki edukacyjnej (pp. 175-187). Katowice: Wydawnictwo Uniwersytetu Śląskiego.

Skotnicka, B. (2017). Szkoła inkluzyjna jako organizacja ucząca się. Niepełnosprawność - zagadnienia, problemy, rozwiqzania, 25, pp. 75-85.

Sochańska-Kawiecka, M., Makowska-Belta, E., Milczarek, D., Morysińska, A., \& Zielińska, D.A. (2015). Włączający system edukacji i rynku pracy - rekomendacje dla polityki publicznej. Warszawa: Instytut Badań Edukacyjnych.

Szumski,G.(2010). Wokółedukacji włączajq̨cej.Efektykształceniauczniówzniepełnosprawnościq intelektualnq w stopniu lekkim w klasach specjalnych, integracyjnych i ogólnodostępnych. Warszawa: Wydawnictwo Akademii Pedagogiki Specjalnej.

Szumski, G. (2013). Integracyjne kształcenie niepełnosprawnych. Sens i granice zmiany edukacyjnej. Warszawa: Wydawnictwo APS i Wydawnictwo Naukowe PWN.

Uberman, M., \& Mach, A. (2016). Kompetencje nauczyciela edukacji wczesnoszkolnej w szkole ogólnodostępnej w pracy z dzieckiem z niepełnosprawnością. Lubelski Rocznik Pedagogiczny, 35(3), pp. 165-185. DOI: 10.17951/lrp.2016.35.3.165.

Zamkowska, A. (2009). Wsparcie edukacyjne uczniów z upośledzeniem umysłowym w stopniu lekkim w różnych formach kształcenia na I etapie edukacji. Radom: Wydawnictwo Politechniki Radomskiej.

Zamkowska, A. (2011). Bariery i uwarunkowania edukacji włączającej. In: Z. Gajdzica (Ed.), Uczeń z niepełnosprawnościq w szkole ogólnodostępnej (pp. 24-33). Sosnowiec: Oficyna Wydawnicza „Humanitas” WSH. 